\title{
Does bullous erythema ab igne develop easier in diabetics? A case series of four patients
}

Büllöz eritema ab igne diabetiklerde daha kolay mı gelişiyor? Dört hastadan oluşan bir olgu serisi

\author{
Habibullah Aktas', Ali Ramazan Benli², Ersin Aydin ${ }^{3}$, Isa An ${ }^{4}$
}

\begin{abstract}
Erythema ab igne is a skin disease produced by chronic heat exposure. It is manifested by reticulate erythema and pigmentation with or without subjective symptoms mainly on the lower extremities. Erythema ab igne has significance due to its malignant potential. Bullous type erythema ab igne is very rare, and its association with diabetes mellitus has not been mentioned yet.

In this paper, we present four diabetic patients with bullous erythema ab igne and emphasize the importance of avoiding chronic heat exposure, particularly in diabetic patients.

Key words: bullous erythema ab igne, diabetes, malignancy
\end{abstract}

\section{Öz}

Eritema ab igne kronik 1Sı maruziyetinin meydana getirdiği bir deri hastalığıdır. Özellikle alt ekstremitelerde subjektif belirtileri de olabilen ağ benzeri eritem ve pigmentasyonla kendini belli eder. Eritema ab igne malign potansiyeli nedeniyle önem taşır. Büllöz lezyonların eşlik ettiği eritem ab igne çok nadirdir ve şimdiye kadar diabetle ilişkisinden bahsedilmemiştir. Bu makalede büllöz eritema ab igne tanısı konulan dört diabetik hastayı sunuyor ve özellikle diabetik hastalarda kronik 1S1 maruziyetinin sakıncalarına vurgu yapıyoruz.

Anahtar kelimeler: büllöz eritema ab igne, diabet, malignensi

\section{Introduction}

Erythema ab igne (EAI) is a cutaneous condition produced from chronic heat exposure. It is manifested by reticulate dusky erythema and its residual pigmentation. Although EAI is commonly seen on the lower extremities, other body areas such as the back, the lumbar region, the arms, even the face, exposed to a heating source may be involved. The disease is often asymptomatic, but rarely burning sensation and mild pruritus have been described in some patients [1]. The histopathology of erythema ab igne is generally nonspecific and non-diagnostic, so the diagnosis is mainly clinical [2].

EAI associated with bullous lesions is very rare, and it has been suggested that it could be a late-stage of EAI. As heating time increases, theoretically possibility of the development of bullous lesions also increases [2]. Additionally, its association with diabetes mellitus has not been mentioned yet.

\section{Case Reports}

There were four male diabetic patients with erythema ab igne associated with bullous lesions. Their ages ranged from 34 to 54 years, with an average of 46.5 years. There were four male diabetic patients with erythema ab igne associated with bullous lesions. Their ages ranged from 34 to 54 years, with an average of 46.5 years. All the patients were diabetic; one was on oral anti-diabetic drug therapy while the others had been on insulin treatment. One of the patients had hypothyroidism as well.
1 Karabuk University Faculty of Medicine, Department of Dermatology, Karabuk, Turkey. Karabük Üniversitesi Tıp Fakültesi, Dermatoloji Anabilim Dalı, Karabük, Türkiye.

${ }_{2}$ Karabuk University Faculty of Medicine, Department of Family Medicine, Karabuk, Turkey.

Karabük Üniversitesi Tıp Fakültesi, Aile Hekimliği Anabilim Dalı, Karabük, Türkiye.

${ }^{3}$ Private Dermatologist, İstanbul, Turkey.

Serbest Hekim, Dermatoloji Uzmanı, İstanbul, Türkiye.

4 Dicle University Faculty of Medicine, Department of Dermatology, Diyarbakir, Turkey.

Dicle Üniversitesi Tıp Fakültesi, Dermatoloji Anabilim Dalı, Diyarbakır, Türkiye.

Çıkar Çatışması: Yazarlar çıkar çatışması bildirmemişlerdir.

Conflict of Interest: No conflict of interest was declared by the authors.

Finansal Destek: Yazarlar bu olgu için finansal destek almadıklarını beyan etmişlerdir.

Financial Disclosure: The authors declared that this case has received no financial support.

Geliş Tarihi / Received

11.06.2017

Kabul Tarihi / Accepted

21.07.2017

Yayın Tarihi / Published

01.12.2017

Sorumlu yazar / Corresponding author

Habibullah Aktaş,

Adres/Address: Karabük Üni. Tip Fak. Dermatoloj Bölümü

Karabük Eğitim ve Araştırma Hastanesi Cildiye Kliniği,

Karabük, Türkiye

Tel : +90 5324084611

E-posta:aktashabib@hotmail.com

Copyright 2017 ACEM 
The patients admitted to our dermatology outpatient clinics with the complaints of redness and bullae on their lower extremities. In dermatological examinations, bilateral reticulated erythematous and hyperpigmented macules with bullous lesions were observed on the medial and anterior aspects of the legs in various stages (Figure a-d). In history, all of them revealed an electrical heater use close to their lower extremities throughout the day for several weeks. The patients were unaware that the heater device could cause to the problem. Typical appearance of the lesions on a well-known localization associated with the history of use of heating source helped us to put the diagnosis of EAI. Diabetic bullae may be a differential diagnosis; however, no biopsy procedure was needed for the bullae since the histopathological features were not pathognomonic in both bullous lesions of erythema ab igne and diabetic bullae. The patients were warned about the significance of the disease implying its malignancy potential and recommended absolute avoiding from heater use. A topical antibiotic ointment (mupirocin or fucidic acid) was prescribed to prevent secondary bacterial infections, recommending at least two weeks.

Written consent could not be taken from the retrospective design of the study.

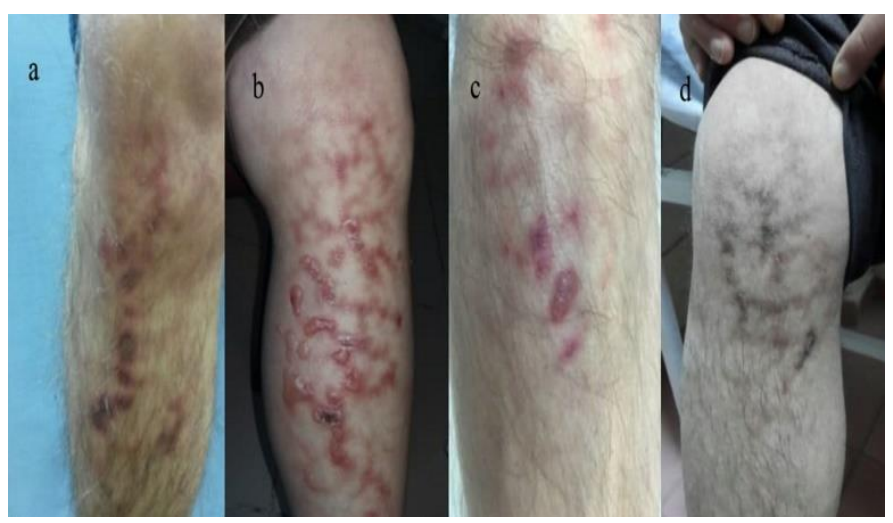

Figure:(From a to d) Erythema ab igne bullous and crusted lesions in the lower extremities.

\section{Discussion}

Although EAI is seen mostly in women, the patients in the present study were all male. We could not impose a rationale for the explanation about the detection of all bullous lesions in men. Due to the presence of only four patients, it is impossible to indicate a general rule. However, male patients may be more exposed to electrical heater use because of working situations outside of their home.

Bullous lesions with typical erythema ab igne presentation have been rarely reported in the literature [1,3-5]. Although diabetes associated EAI cases were reported in the literature, none of them did notice a possible association between bullous type EAI and diabetes mellitus [6,7].

Turan et al. reported a bullous EAI case with hypothyroidism like one of our patients and discussed that hypothermia seen in anemia and hypothyroidism may be detected in EAI cases [5]. EAI occurred within two months after heat exposure in Turan's case. It is likely that hypotermia in the patient could provoke more exposure time to heat giving rise to the development of bullous lesions.

Peripheral neuropathy is a well-known complication seen especially in poorly controlled and long standing diabetic patients. Those patients with diabetic neuropathy are not be able to feel pain or high temperature properly, so it is likely that they stay much more time close to a heating source without feeling of burning. The development of bullae may be related with this long standing exposing time in diabetic patients.

EAI has an important issue that malignant neoplasms such as Squamous cell and Merkel cell carcinomas might develop over the lesions as the time progresses if the heat exposure continues [8,9]. Since bullous EAI may indicate a long-term exposure to heat, it is logical to propose that risk of malignancy may be higher in bullous type EAI cases. All people not only diabetic patients should be alerted about this condition by their physicians.

\section{References}

1. Kokturk A, Kaya TI, Baz K, Yazici AC, Apa DD, Ikizoglu G. Bullous erythema ab igne. Dermatol Online J 2003; 9: 18.

2. Kristen M, Raegan H, Julie C, Shane M, Jennifer S. Erythema ab igne. Dermatol Online J 2011; 17: 28.

3. Asilian A, Abtahi-Naeini B, Pourazizi M, Rakhshanpour M. Rapid Onset of Bullous Erythema Ab Igne: A Case Report of Atypical Presentation. Indian J of Dermatol 2015; 60: 325.

4. Flanagan N, Watson R, Sweeney E, Barnes L. Bullous erythema ab igne. Br J Dermatol 1996; 134: 1159-60.

5. Turan E, Çimen V, Kutlu Haytoglu NS, Göde ED, Gürel MS. A Case of Bullous Erythema Ab Igne Accompanied by Anemia and Subclinical Hypothyroidism. Dermatol Online J 2014; 20: 22336.

6. Milgrom Y, Sabag T, Zlotogorski A, Heyman S N. Erythema ab igne of shins: A kerosene stove-induced prototype in diabetics. J Postgrad Med 2013; 59: 56-7.

7. Sesay M, Dhanji S. Case report: Erythema ab igne in a patient with diabetic neuropathy. Am Fam Physician 2009; 80: 322.

8. Hewitt JB, Sherif A, Kerr KM, StanklerL. Merkel cell and squamous cell carcinomas arising in erythema ab igne. $\mathrm{Br} \mathrm{J}$ Dermatol 1993; 128: 591-2.

9. Sigmon JR, Cantrell J, Teague D, Sangueza O, Sheean DJ. Poorly differentiated carcinoma arising in the setting of erythema ab igne. Am J Dermatopathology 2013; 35: 676-8. 